\title{
The Effect of a Minimum Youth Wage in New Zealand
}

\author{
Raymond Harbridge and Julia Lane*
}

\section{Introduction}

Twice in the last decade, youth rates of pay have been a very contentious issue. In 1983, two Government Members of Parliament voted with the Opposition to defeat a National Government proposal. The effect of that proposal was that no employer could be required to pay a worker under 18 years of age the same ordinary time rate as they paid an adult worker. Under the proposal, mandatory youth rates of pay would have been imposed on union negotiated awards and collective agreements that contained no such youth pay rates. These Members of Parliament, Marilyn Waring and Michael Minogue, told Parliament that the implications of the proposal for low paid workers, particularly women, were unacceptable in both social and human terms (Hansard, 1983). In 1983 this view won the day and youth rates remained subject to negotiation in collective bargaining rather than being imposed by legislative provision. A decade later, in May 1993, the peak council of unions in New Zealand, the New Zealand Council of Trade Unions, has argued for the introduction of a legislated minimum wage for youth and for the adult minimum wage to apply to workers once they reach 19 years of age (New Zealand Council of Trade Unions, 1993). And more recently, in July, a Labour opposition Member of Parliament has introduced a Private Members Bill to Parliament seeking to introduce a legislated minimum wage for youth workers.

This juxtaposition of views in the one decade is a direct result of the effects of the Employment Contracts Act 1991 (ECA). Two years after its implementation, the ECA has decimated collective bargaining (particularly multi-employer bargaining), reducing collective bargaining coverage by 60 percent and removing some 400,000 employees from the collective bargaining system (Harbridge and Hince, 1993). In the absence of a union negotiated collective bargain, attention has focused on the statutory minima that regulate the engagement of labour. While some 60 percent of the workforce had been covered by a collective bargain (as had been the case in 1989/90), there had been only scant development of a statutory minimum code of employment. In particular, although a statutory minimum wage for adults (20 year olds and over) had been in place since $1945^{1}$, no such statute made provision for youth. Now, in the absence of a network of multiemployer collective bargains, demand for a statutory minimum youth wage is seen by many as a mechanism for protecting youth against wage exploitation by some employers.

* Associate Professor, Industrial Relations Centre, Victoria University of Wellington, New Zealand and Professor, Economics Department, The American University, Washington DC, USA respectively. This research was supported by a research grant from the Ministry of Youth Affairs.

$1 \quad$ Currently $\$ 245$ per week. 
The literature has a great deal to say about the theoretical and empirical effects of minimum wages on employment and unemployment. The theoretical view is straightforward: in a simple competitive neoclassical model, an increase in minimum wages will increase unemployment by increasing quantity supplied by workers and reducing quantity demanded by firms. This would increase unemployment in the covered sector.

The empirical evidence from the United States has been very provocative. Katz and Krueger (1992) use firm-based data in finding no evidence to support the belief that increases in youth wages will reduce employment. Card (1992a, 1992b), in the same symposium on minimum wages, agrees with this view, although Neumark and Wachter (1992) use earlier data and a different model to disagree. There does, however, appear to be some consensus (Wellington, 1991; Brown, 1988) arguing that the effects, if any, of minimum wage legislation are borne most heavily by youth and unskilled workers. from no effect to a one percent drop in employment for every 10 percent increase in earnings.

One major reason for such a small effect is, as Katz and Krueger point out, that not many firms use the youth subminimum wage (Katz and Krueger, 1992: 20). It is reasonable, in light of the American literature, to wonder what the effects of a legislated minimum youth wage would be in New Zealand, and to begin with an analysis of the impact on the firm.

In the absence of similar New Zealand data, it is difficult to have informed debate of the effects of a New Zealand youth minimum wage. Since much of the debate focuses on the costs and burdens to the firm associated with the imposition of the minimum wage, it would be useful in analysis of these costs and burdens to know what firms are currently paying youths. Thus, one way to infer the magnitude of the impact is to survey the collective paid, and determine the characteristics of those contracts. That is the focus of this study. In particular, we attempt to provide substance to the New Zealand debate by answering the following questions:

1. What would be the impact of a $\$ 180$ or $\$ 200$ youth weekly wage for 16 and 17 year olds?

2. What would be the impact on firms (sector by sector) if the minimum adult wage were set at 18 years?

3. Would the impact be greater on mainly male or mainly female dominated contracts?

4. Would the impacts of a youth minimum wage differ by contract size?

The following section describes the method that was used to obtain the data and provides an overview of the industry and employment coverage. This is followed by an analysis of the results and a discussion of the implications of the study.

\section{Method}

The ECA has abolished the requirement for registration of collective bargains. In the absence of a public record of collective bargaining, a pro-active approach to primary data gathering has been adopted. Three surveys of employers (1,200 with 50 or more staff, 1,400 with between 20 and 50 staff and 2,000 with fewer than 20 staff) undertaken. In addition, all of New Zealand's unions have been surveyed. Those surveyed have been asked to supply, on a strictly confidential basis, any collective employment contracts they have entered into, so as to compile a contracts database. As contracts expire requests are made for any replacement contracts. At June 1993, the database contained 1,630 collective employment contracts covering slightly more than 9,000 employers and 287,000 workers. This sample represents 63 percent of the unionised workforce as at 31 December 1992, 38 percent of workers covered by collective settlemeds under the "old system, or 25 percent of the current full-time workforce. Approximately 33 percent of contracts have been supplied by employers; the remainder by unions.

Each contract has been examined and a number of variables recorded. For the purposes of this study, the relevant variables identified were: industry (at two digit Standard Industry Classification level); total number of workers covered by the contract; number of employers covered by the contract; the percentage of covered workers who were women; and the type of contract (multi or single employer or union). Further information about the data gathering and contract analysis method is available in Harbridge and Moulder (1993).

In addition, each contract was examined to identify whether or not that contract contained youth rates of pay. Where youth rates have been identified the contract has been further reviewed to identify the lowest weekly rate of pay applicable to a 16,17,18 and 19 year old. Where more than one rate for an age level has been expressed (for example, different rate for a clerk and a labourer), the lower rate has been recorded. Where pay rates have been expressed as hourly or annual rates of pay, these have been converted to weekly rates. Where youth rates are expressed as a percentage of the applicable minimum adult rate in the contract, this also has been converted to the applicable weekly rate.

While the total number of workers covered by the contract has been identified and recorded, it has not been possible to identify the number of youths employed under the terms of contract.

The wage rates recorded need to be seen in context. They are rates of pay for youth specified in collective employment contracts, most of which are single employer, enterprise contracts. The existence of these rates neither necessarily indicates that youth are indeed employed nor that youth are actually paid these rates. The rates could well be minimums with the employer paying actual rates in excess of these minimums and there may be no youths engaged anyway. Nontheless, given the enterprise nature of these contrac seems likly that encts, it seems likely that employers specifying youth rates in their collective employment contracts are indeed engaging youth and are paying them the rates specified. There seems little point in specifying such rates otherwise. 
No analysis of contracts where youth rates are absent has been undertaken. That youth rates are absent would be no guarantee that youth were not engaged anyway and paid youth rates. The Employment Contracts Act contains no automatic provision for the extension of collective employment contracts to all existing or any new employees. Accordingly it is possible (and quite likely) for youth to be engaged on individual contracts outside the collective contract. For this reason, an analysis of the contracts which do not contain youth rates would be no guarantee that youths were employed at adult rates of pay and such an analysis would provide little valid information.

\section{Results}

Some of the collective employment contracts held contain no rates of pay at all - let alone youth rates of pay. There are 261 contracts (covering 28,000 workers) where no pay rates are mentioned. Others contain only adult rates of pay or apply only to those workers who have signed the contract at the date of settlement. Nonetheless, an exhaustive analysis of those contracts that had been already identified as containing youth rates of pay has produced a dataset of 610 contracts covering 142,000 workers and 5,200 employers. Conversely, there are 759 contracts (covering 118,000 workers) which contain adult rates of pay but no youth rates. The distribution and coverage of contracts containing youth rates by industry is presented in Table 1 .

Table 1: The distribution and coverage of collective employment contracts containing youth rates of pay by industry

\section{Industry}

Agriculture

Mining

Energy

Construction

Wholesale, retail, hotel, etc

Finance

Community, public services

Other

$\underline{\text { Totals }}$
Manufacturing

Transport, communication

\section{No of contracts}

Coverage

\section{\% Coverage}

$$
\begin{array}{r}
801 \\
50 \\
27,196 \\
3,718 \\
1,299 \\
26,584 \\
21,847 \\
16,744 \\
43,144
\end{array}
$$$$
50
$$$$
\begin{aligned}
& 3,718 \\
& 1,299
\end{aligned}
$$$$
26,584
$$$$
26,584
$$$$
\begin{aligned}
& 21,847 \\
& 16,744
\end{aligned}
$$

$0 \%$
$0 \%$
$19 \%$
$3 \%$
$1 \%$
$19 \%$
$16 \%$
$12 \%$
$30 \%$
$0 \%$

$19 \%$

$16 \%$

$30 \%$
Ant 13 of these contracts were single employer contracts. The 13 multi-employe contracts covered about 22,000 workers. Unions negotiated 507 (83 percent) of the contracts covering 130,000 workers ( 92 percent). Youth pay rates were expressed as a percentage of the rate of the applicable minimum adult rate in 41 percent of contracts. Data

\begin{tabular}{|c|c|c|c|c|}
\hline & $16 \mathrm{yr}$ old & $17 \mathrm{yr}$ old & $18 \mathrm{yr}$ old & 19 yr old \\
\hline Minimum & $\$ 142$ & $\$ 154$ & $\$ 159$ & $\$ 159$ \\
\hline $25 \%$ & $\$ 187$ & $\$ 211$ & $\$ 232$ & $\$ 248$ \\
\hline $50 \%$ & $\$ 226$ & $\$ 240$ & $\$ 280$ & $\$ 306$ \\
\hline $75 \%$ & $\$ 264$ & $\$ 285$ & $\$ 317$ & $\$ 330$ \\
\hline Maximum & $\$ 408$ & $\$ 408$ & $\$ 480$ & $\$ 480$ \\
\hline$\underline{\mathrm{SD}}$ & $\$ 53$ & $\$ 50$ & $\$ 55$ & $\$ 56$ \\
\hline
\end{tabular}
for youth pay by age are presented in Table 2 . The same data by sector are presented in the Appendix.

\section{Table 2: The distribution of youth pay by age}

There are several main results which come out of the analysis. First, the youth wage rates currently in place differ substantially across sectors of the economy. In particular, while very few contracts in the public sector provide for 16 and 17 year olds to be paid wages below $\$ 200$ a week, more than half of all contracts in the wholesale/retail/hotel sector pay 16 year olds that amount or less. Second, applying the current minimum adult wage to 18 year olds would affect approximately one quarter of the firms in our sample, but over half of firms in the energy and public sectors. Third, a youth minimum wage for 16 and 17 year olds would disproportionately affect the mainly male contracts; the reverse would be the case for a minimum wage for 18 and 19 year olds. Each of these results is described in more detail below. Finally, there is little disparate impact by size of contract.

\section{What would be the impact of a $16 / 17$ year old minimum wage?}

A summary of the youth wage rate distribution by sector and age is provided in the appendix. The response to this question may be seen from the Tables, the Appendix and Figure 1 . In brief, a 16/17 year old minimum wage set at $\$ 200$ would affect 190 contracts covering 33,000 workers; set at $\$ 180$ it would affect 127 contracts, covering 17,000 workers. If the same wages were set for 17 year olds only, the effects would be even more negligible: only 28 contracts (covering 3,000 workers) in the sample pay 17 year olds less than $\$ 180 ; 69$ contracts (covering 23,000 workers) pay less than $\$ 200$ 
The effects are markedly different by industry. Almost all the contracts in the agriculture Tector pay wages under \$180 to 16 year olds although only half that number pay under $\$ 200$ for 17 year olds. Only one contact in the energy sector pays under \$200 to either 16 or 17 year old; non 16 or 17 year olds, none pay under that ame in the 17 year olds in the transport and communication sector; and only seven (five) in the financial services sector pay under to 16 (17) year olds. The sector most affected would be the wholesale/retail/hotel sector: currently 38 (26) of the 75 contracts in the sample pay less than the $\$ 200$ to 16 (17) year olds.

Figure 1: Youth Wage Rates by Sector and Quartile

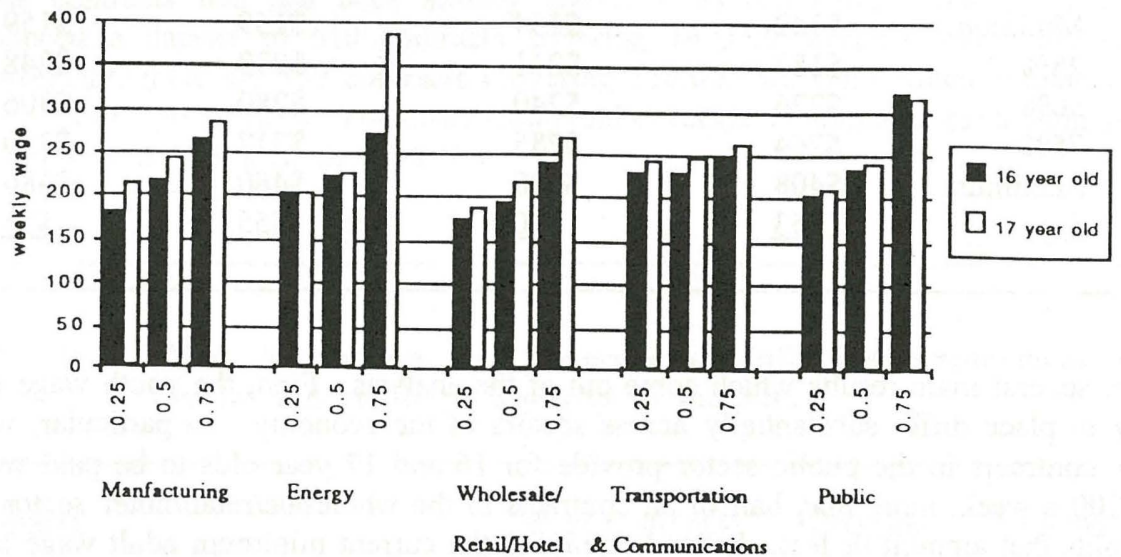

2. The effect of a minimum adult wage set at 18 years

The Table, the Appendix and Figure 2 reveal that allowing the minimum adult wage to apply to 18 and 19 year olds would actually affect less than a quarter of the contracts containing youth rates in this survey. The contracts which would be affected do however tend to be larger, and some 56,000 employees are covered by them, about 40 percent of employees covered in all the contracts containing youth rates.
Figure 2: Youth Wage Rates by Sector and Quartile

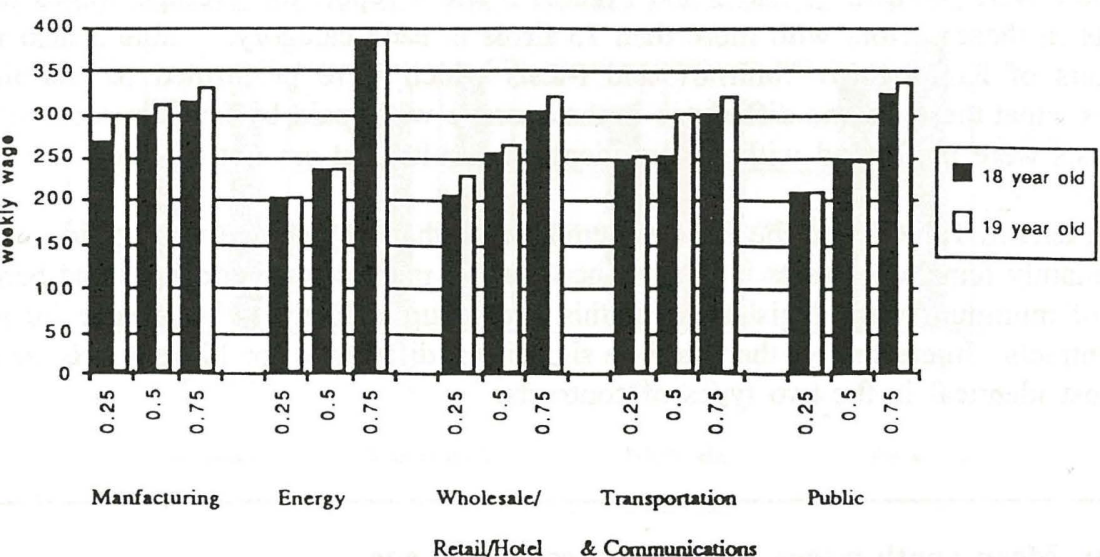

In particular, the effect on construction and transportation firms is almost negligible: one out of the six contracts in construction currently pays 18 year olds less than $\$ 245$ a week and none pays 19 year olds less. Similarly, in the transport and communication sector, only three out of the 29 contracts held pay less than the current adult wage. The effects in manufacturing are also negligible: 43 (30) contracts out of 316 gave 18 (19) year olds less than the minimum adult wage. Just over one third of contracts in the wholesale/retail/hotel sector would be affected, with 27 of 75 giving 19 year olds below the adult minimum. The effect would be most marked in the financial, public and energy sectors. Twenty-five (24) of the 42 contracts in finance paid below the $\$ 245$ mark for 18 (19) year olds; 46 (46) out of 99 contracts in the public sector, and 14 (14) out of 26 contracts in energy paid below $\$ 245$ for 18 (19) year olds.

One very interesting result obtained from the data is that firms appear to make very different decisions about how much to pay the different age groups. The fact that some thought has gone into the setting of the youth wages is evident from a simple correlation of the youth rates by age groups. In particular, 16 year old wages are almost exactly correlated with 17 year old rates: the correlation coefficient is 0.97 . However, the correlation between 16 year old wage rates and 18 year old wage rates is only 0.71 , and between 16 year old rates and 19 year olds only 0.55 . This suggests that firms are not blindly setting rates for youths in lock step with their age.

It is further interesting to note that there is quite a sharp demarcation between the wage rates for $16 / 17$ year old youth and 18/19 year old youth. The correlations reported above demonstrate that firms seem to set almost identical rates for 16 and 17 year olds; similarly the correlation between 18 and 19 year old wages is 0.92 . Thus there may be some reason to set 18 as a breakpoint in the decision to set a minimum adult wage for youth 
3. What would the impact be on mainly female contracts?

We followed Hammond and Harbridge (1993) and defined a contract as mainly female if more than $56 \%$ of the work force were women and mainly male if less than $44 \%$ of the work force were women. Table 3 and Figures 3 and 4 report the average wages paid for contracts in those sectors with more than 15 firms in each category. Table 3 also reports the results of Kolmogorov Smirnov and t-tests which were performed to test the null hypothesis that there was no difference in the average wage paid by firms in each category. Other tests were performed with almost identical results, but are not reported.

Both the data in Table 3 and the Figures demonstrate that the average wage paid to 16 year olds in mainly female contracts is greater than that for mainly male contracts and hence the impact of minimum wage legislation for this age group is likely to be greater for mainly male contracts. Interestingly, there is little significant difference for 17 year olds, as wages are almost identical in the two types of contracts.

Table 3: Mean youth wages by gender, sector and age

\begin{tabular}{|c|c|c|c|c|}
\hline All sectors & 16 yr old & $17 \mathrm{yr}$ old & 18 yr old & $19 \mathrm{yr}$ old \\
\hline Mainly male contracts & $\$ 220$ & $\$ 250$ & $\$ 288$ & $\$ 309$ \\
\hline Mainly female contracts & $\$ 249$ & $\$ 255$ & $\$ 273$ & $\$ 280$ \\
\hline $\mathrm{K}-\mathrm{S}$ & $2.5^{*}$ & 1.14 & $2.5^{*}$ & $2.6^{*}$ \\
\hline t-test & $5.46^{*}$ & 1.27 & $-1.99 *$ & $-4.24 *$ \\
\hline Manufacturing & 16 yr old & $17 \mathrm{yr}$ old & $18 \mathrm{yr}$ old & $19 \mathrm{yr}$ old \\
\hline Mainly male contracts & $\$ 215$ & $\$ 249$ & $\$ 296$ & $\$ 319$ \\
\hline Mainly female contracts & $\$ 246$ & $\$ 255$ & $\$ 285$ & $\$ 291$ \\
\hline $\mathrm{K}-\mathrm{S}$ & $2.78^{*}$ & $1.50^{*}$ & $1.71^{*}$ & $2.39 *$ \\
\hline t-test & $4.71^{*}$ & 1.76 & -0.06 & $-2.52 *$ \\
\hline Trade/retail/hotel & $16 \mathrm{yr}$ old & 17 yr old & 18 yr old & 19 yr old \\
\hline Mainly male contracts & $\$ 213$ & $\$ 238$ & $\$ 270$ & $\$ 287$ \\
\hline Mainly female contracts & $\$ 203$ & $\$ 221$ & $\$ 245$ & $\$ 266$ \\
\hline K-S & 0.91 & 0.83 & 0.98 & 1.31 \\
\hline t-test & 0.60 & 1.3 & 1.87 & 1.59 \\
\hline$\underline{\text { Public }}$ & 16 yr old & 17 yr old & 18 yr old & 19 yr old \\
\hline Mainly male contracts & $\$ 243$ & $\$ 246$ & $\$ 286$ & $\$ 269$ \\
\hline Mainly female contracts & $\$ 281$ & $\$ 281$ & $\$ 253$ & $\$ 288$ \\
\hline $\mathrm{K}-\mathrm{S}$ & $1.57^{*}$ & $1.44 *$ & $1.44 *$ & $1.57^{*}$ \\
\hline t-test & $2.06^{*}$ & 1.90 & -1.70 & 0.83 \\
\hline
\end{tabular}

* significant at the $5 \%$ level of significance
Figure 3: Mean Youth Wage Rates In Mainly Male and Mainly Female Contracts

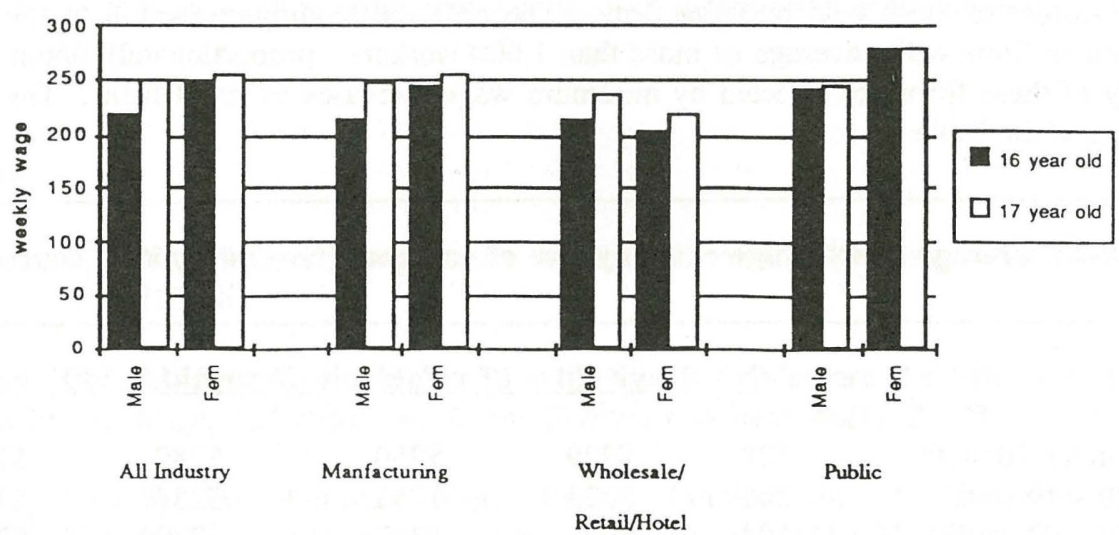

Figure 4: Mean Youth Wage Rates in Mainly Male and Mainly Female Contracts

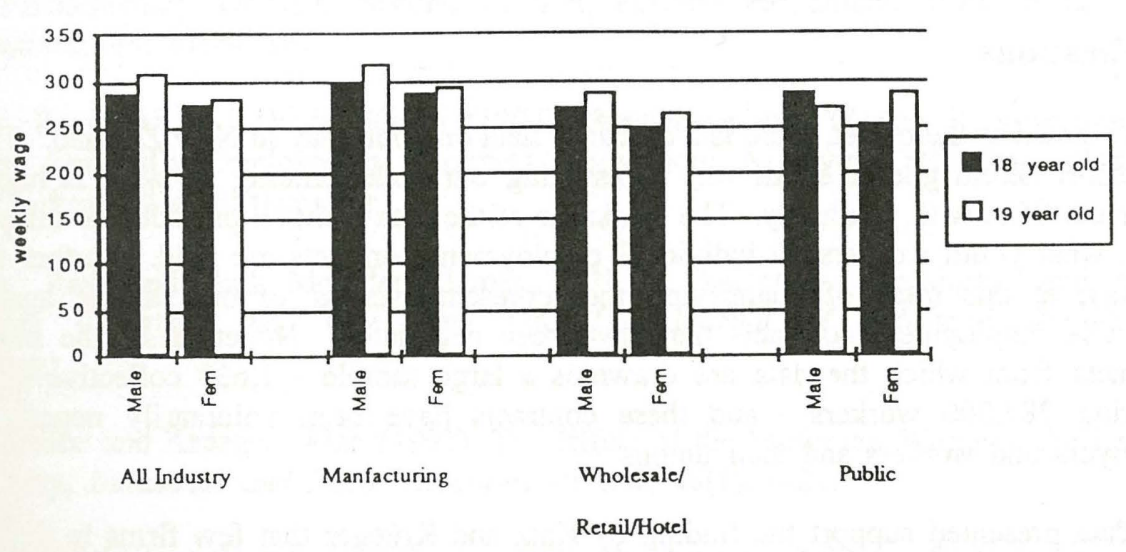

The impact of minimum wage legislation for 18 and 19 year olds would be the reverse of that for the younger group. Mainly male contracts actually pay a significantly higher wage for youth than do mainly female contracts in both age categories. Again, the industry differences are especially interesting: the reported pattern is confirmed in the manufacturing and public sectors, but there appears to be no significant difference in earnings in wholesale/retail/hotel trade. 


\section{Are small contracts affected more than large contracts?}

A brief answer to this question is no. Small firms appear to pay youth wage rates that are very similar to those paid by large firms. The only outstanding exception to this general answer is firms with coverage of more than 1,000 workers - proportionately about twice as many of these firms are affected by minimum wage increases as small firms. The data are presented in Table 4.

Table 4: Average youth wage rates by size of contract $(\mathrm{N}=$ number of contracts $)$

\begin{tabular}{|c|c|c|c|c|c|}
\hline & $\underline{\mathbf{N}}$ & $16 \mathrm{yr}$ old & $\underline{17 \mathrm{yr} \text { old }}$ & 18 yr old & $19 \mathrm{yr}$ old \\
\hline Under 20 staff & 128 & $\$ 229$ & $\$ 250$ & $\$ 280$ & $\$ 299$ \\
\hline 20 - 49 staff & 205 & $\$ 233$ & $\$ 253$ & $\$ 287$ & $\$ 303$ \\
\hline 50 - 99 staff & 104 & $\$ 221$ & $\$ 247$ & $\$ 279$ & $\$ 294$ \\
\hline $100-999$ staff & 136 & $\$ 227$ & $\$ 247$ & $\$ 273$ & $\$ 286$ \\
\hline Over 1000 staff & 30 & $\$ 230$ & $\$ 242$ & $\$ 256$ & $\$ 268$ \\
\hline
\end{tabular}

\section{Implications}

As we stated at the outset, there is a dearth of data on youth pay in New Zealand. The data we report herein goes a small way to assisting our understanding of what is happening under the ECA with youth pay. The weakness of the data is that it provides no information about what youth workers on individual employment contracts are paid. Further there is no way, at this time, of quantifying the representativeness of our sample against all

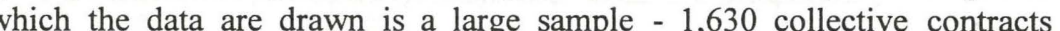
covering 287,000 workers - and these contracts have been voluntarily negotiated by employers and workers and their unions.

The data presented support the finding by Katz and Krueger that few firms in the United States use subminimum wage rates for youth. In New Zealand, a majority of the collective contracts examined do not contain youth rates and those that do often contain youth rates that exceed the adult minimum wage.

The data suggest that the position adopted by the New Zealand Council of Trade Unions, that the minimum wage should be applied to 19 year olds, is a conservative position and that few contracts would be affected by lowering the introduction of the minimum wage to those 18 years of age and over.

Finally, a single minimum youth wage set for 16 and 17 year olds at $\$ 180$ per week would affect about 20 percent of the contracts representing just 12 percent of all workers covered by the sample. A youth wage that differentiated between 16 and 17 year olds, and was set at $\$ 180$ per week for 17 year olds would affect just 28 contracts covering 3,000 workers.

The provision of this data and analysis may be useful in determining public policy on this contentious matter.

\section{References}

Brown, Charles (1988), Minimum Wage Laws: Are they Over-rated?, Journal of Economic Perspectives, 2(3): 133-46.

Card David (1992a), Using Regional Variation in Wages to Measure the Effects of the Federal Minimum Wage, Industrial and Labor Relations Review, 46(1): 22-37.

Card, David (1992b), Do Minimum Wages Reduce Employment? A Case Study of California: 1987-1989, Industrial and Labor Relations Review, 46(1): 38-45.

Hammond, Suzanne and Harbridge, Raymond (1993), The Impact of the Employment Contracts Act on Women at Work, New Zealand Journal of Industrial Relations, 18(1): 1530.

Hansard Parliamentary Debates: Second Session, Fortieth Parliament, 1983: House of Representatives, 45: 4105-5162

Harbridge, Raymond and Hince, Kevin (1993), Bargaining and Worker Representation under New Zealand's Employment Contracts Legislation: A Review after Two Years, Relations Industrielles (forthcoming)

Harbridge, Raymond and Moulder, James (1993), Collective Bargaining and the Employment Contracts Act: One Year On, The Journal of Industrial Relations (forthcoming).

Katz, Lawrence and Krueger, Alan (1992), The Effect of the Minimum Wage on the FastFood Industry, Industrial and Labor Relations Review, 46(1): 6-21.

Newumark, David and Wascher, William (1992), Employment Effects of Minimum and Subminimum Wages: Panel Data on State Minimum Wage Laws, Industrial and Labor Relations Review, 46(1): 55-81

New Zealand Council of Trade Union (1993), Building Better Working Rights: A Minimum Code of Employment Conditions. Circular No 1993/19, Wellington, New Zealand Council of Trade Unions.

Wellington, Alison (1991), Effects of the Minimum Wage on the Employment Status of Youths: An Update, Journal of Human Resources, 26(1): 27-46. 
Appendix 1: The distribution of youth pay by age and industry

\begin{tabular}{lrr}
\multicolumn{1}{r}{ Energy } & $\begin{array}{r}\text { (26 contracts covering } \\
\mathbf{1 6} \text { yr old }\end{array}$ & $\begin{array}{r}\mathbf{1 7} \text { yr old } \\
\text { Minployees }\end{array}$ \\
Minimum & $\$ 198$ & $\$ 198$ \\
$25 \%$ & $\$ 205$ & $\$ 205$ \\
$50 \%$ & $\$ 223$ & $\$ 227$ \\
$75 \%$ & $\$ 272$ & $\$ 386$ \\
Maximum & $\$ 357$ & $\$ 408$ \\
SD & $\$ 39$ & $\$ 84$
\end{tabular}

Finance (42 contracts covering 17,000 employees)

$\begin{array}{lrrr}\text { Minimum } & \mathbf{1 6} \text { yr old } & \mathbf{1 7} \text { yr old } & \mathbf{1 8} \text { yr old } \\ 25 \% & \$ 155 & \$ 158 & \$ 159 \\ 50 \% & \$ 223 & \$ 221 & \$ 224 \\ 75 \% & \$ 227 & \$ 227 & \$ 230 \\ \text { Maximum } & \$ 235 & \$ 235 & \$ 285 \\ \text { SD } & \$ 357 & \$ 357 & \$ 357 \\ & \$ 41 & \$ 41 & \$ 45\end{array}$

\section{8 yr old}

$\$ 198$

$\$ 205$

$\$ 386$

$\$ 426$

$\$ 86$
19 yr old

$\$ 198$

$\$ 205$

$\$ 386$

$\$ 426$

$\$ 88$

19 yr old

$\$ 159$

$\$ 224$

$\$ 232$

$\$ 312$

$\$ 51$

Manufacturing (315 contracts covering 27,000 employees)

$\begin{array}{lrrr}\text { Minimum } & \mathbf{1 6} \text { yr old } & \mathbf{1 7} \text { yr old } & \mathbf{1 8} \text { yr old } \\ 25 \% & \$ 143 & \$ 165 & \$ 184 \\ 50 \% & \$ 180 & \$ 214 & \$ 270 \\ 75 \% & \$ 218 & \$ 245 & \$ 295 \\ \text { Maximum } & \$ 268 & \$ 285 & \$ 317 \\ \text { SD } & \$ 408 & \$ 408 & \$ 480 \\ & \$ 53 & \$ 43 & \$ 47\end{array}$

Public (99 contracts covering 43,000 employees)

$\begin{array}{lrrr} & \mathbf{1 6} \text { yr old } & \frac{17 \text { yr old }}{18} \text { yr old } \\ \text { Minimum } & \$ 179 & \$ 179 & \$ 179 \\ 25 \% & \$ 211 & \$ 211 & \$ 211 \\ 50 \% & \$ 248 & \$ 240 & \$ 248 \\ 75 \% & \$ 326 & \$ 317 & \$ 326 \\ \text { Maximum } & \$ 374 & \$ 388 & \$ 374 \\ \text { SD } & \$ 60 & \$ 59 & \$ 60\end{array}$

19 yr old

$\$ 201$

$\$ 313$

$\$ 331$

$\$ 480$

$\$ 44$
Transport and communication (29 contracts, 22,000 employees)

\begin{tabular}{|c|c|c|c|}
\hline $16 \mathrm{yr}$ old & $17 \mathrm{yr}$ old & 18 yr old & 19 yr old \\
\hline$\$ 150$ & $\$ 204$ & $\$ 204$ & $\$ 204$ \\
\hline$\$ 229$ & $\$ 245$ & $\$ 250$ & $\$ 254$ \\
\hline$\$ 231$ & $\$ 249$ & $\$ 253$ & $\$ 305$ \\
\hline$\$ 249$ & $\$ 263$ & $\$ 302$ & $\$ 392$ \\
\hline$\$ 316$ & $\$ 348$ & $\$ 407$ & $\$ 407$ \\
\hline$\$ 31$ & $\$ 34$ & $\$ 44$ & $\$ 48$ \\
\hline
\end{tabular}

Wholesale/retail/hotel (74 contracts covering 27,000 employees)

\begin{tabular}{|c|c|c|c|c|}
\hline & 16 yr old & 17 yr old & 18 yr old & 19 yr old \\
\hline Minimum & $\$ 142$ & $\$ 154$ & $\$ 174$ & $\$ 174$ \\
\hline $25 \%$ & $\$ 174$ & $\$ 187$ & $\$ 209$ & $\$ 229$ \\
\hline $50 \%$ & $\$ 195$ & $\$ 220$ & $\$ 257$ & $\$ 267$ \\
\hline $75 \%$ & $\$ 240$ & $\$ 270$ & $\$ 306$ & $\$ 323$ \\
\hline Maximum & $\$ 336$ & $\$ 336$ & $\$ 391$ & $\$ 391$ \\
\hline & $\$ 44$ & $\$ 48$ & $\$ 55$ & $\$ 53$ \\
\hline
\end{tabular}

Others

Agriculture (17 contracts covering 900 employees)

\begin{tabular}{rrrr}
$\mathbf{1 6}$ yr old & 17 yr old & $\mathbf{1 8}$ yr old & 19 yr old \\
\hline$\$ 153$ & $\$ 160$ & $\$ 160$ & $\$ 160$ \\
$\$ 160$ & $\$ 160$ & $\$ 160$ & $\$ 160$ \\
$\$ 162$ & $\$ 211$ & $\$ 245$ & $\$ 310$ \\
$\$ 252$ & $\$ 253$ & $\$ 312$ & $\$ 320$ \\
$\$ 292$ & $\$ 292$ & $\$ 344$ & $\$ 346$ \\
$\$ 54$ & $\$ 48$ & $\$ 67$ & $\$ 76$
\end{tabular}

Construction (6 contracts covering 1,300 employees)

\begin{tabular}{|c|c|c|c|c|}
\hline 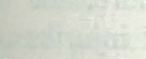 & 16 yr old & 17 yr old & 18 yr old & 19 yr old \\
\hline Minimum & $\$ 153$ & $\$ 214$ & $\$ 240$ & $\$ 278$ \\
\hline $25 \%$ & $\$ 200$ & $\$ 240$ & $\$ 275$ & $\$ 280$ \\
\hline $50 \%$ & $\$ 247$ & $\$ 274$ & $\$ 289$ & $\$ 300$ \\
\hline $75 \%$ & $\$ 300$ & $\$ 300$ & $\$ 300$ & $\$ 306$ \\
\hline Maximum & $\$ 300$ & $\$ 300$ & $\$ 322$ & $\$ 358$ \\
\hline SD & $\$ 61$ & $\$ 34$ & $\$ 28$ & $\$ 29$ \\
\hline
\end{tabular}

